\title{
Sea-bed depths at the mouth of Rutford Ice Stream, Antarctica
}

\author{
A. M. SMith and C. S. M. Doake \\ British Antarctic Survey, Nalural Environment Research Council, Cambridge CB3 OET, England
}

\begin{abstract}
Seismic measurements of ice- and water-column thickness have been made on Rutford Ice Strcam where it joins the Ronne Ice Shelf. Assuming that the ice is in hydrostatic equilibrium, these values have been used to calculate sea-bed elevations. A sea-bed trough more than $2 \mathrm{~km}$ below sea level along the western margin continues downstream from the grounded to the floating ice.
\end{abstract}

\section{INTRODUCTION}

Rutford Ice Stream is a large glacier draining ice from the West Antarctic ice sheet into the Ronne Ice Shelf (Fig. 1). It is bounded to the northeast by the slow-moving ice of Fletcher Promontory and to the southwest by the Ellsworth Mountains. Until recently, ground-based glaciological ficld work on Rutford Ice Stream concentrated mainly on the area upstream of the grounding line. Most of this work involved a combination of optical- and satcllite-survey techniques and radio-echo sounding. Consequently, no measurcments of sea-bed depths at the mouth of the ice stream have been made. Russian seabed-elevation data beneath the Ronne Ice Shelf do not extend far beyond $72^{\circ} \mathrm{W}$ (Pozdeyev and Kurinin, 1987), more than $250 \mathrm{~km}$ from the grounding line of Rutford Ice Stream. Two field seasons of seismic surveys (1991-92 and 1992-93) investigating the bed of the ice stream have just been completed (Smith, in press). These surveys werc also concentrated above the grounding line but a number of seismic spot measurements of ice- and water-column thickness were made beyond where the ice begins to float. The aim of the measurements was to provide input data

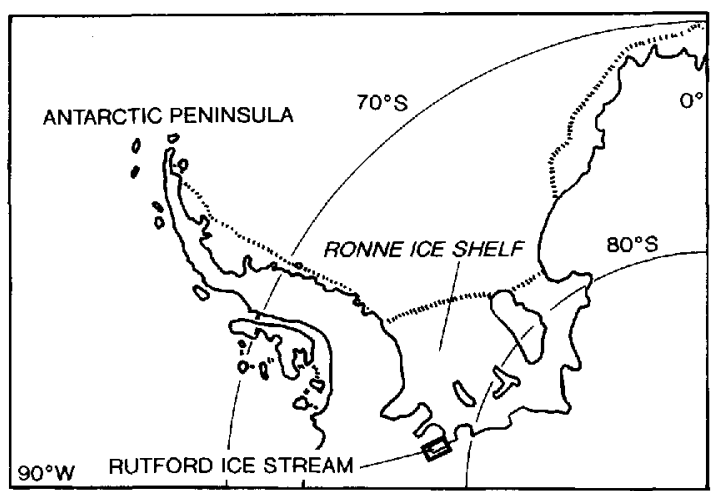

Fig. 1. Location map. The area covered by the maps in Figure 3 is indicated. for both tidal modelling beneath the ice shelf and for modelling the dynamics of thicker ice (or lower sea level) in the ice stream.

\section{SEISMIC SURVEYS}

Depending on the available time and resources, one of three different seismic sources was used: $100 \mathrm{~g}$ explosive charges in back-filled $20 \mathrm{~m}$ holes; $150 \mathrm{~g}$ charges in backfilled $1 \mathrm{~m}$ holes; or a number of hammer blows stacked together (usually $10-15$, but up to a maximum of 35 ). The data were recordcd on a 24-channcl scismograph from geophones at offsets between 30 and $260 \mathrm{~m}$ from the source. Data were recorded digitally and could be processed later, if neccssary. A varicty of rccord lengths $(0.8-2.5 \mathrm{~s})$ and sample intervals $(0.20 .5 \mathrm{~ms})$ were used. Site positions were determined by a combination of deadreckoning round closed loops, controlled by GPS and TRANSIT satellite-position fixes. Positions are generally accurate to within $\pm 200 \mathrm{~m}$.

\section{IDENTIFICATION OF ARRIVALS AND POSSIBLE ERRORS}

The seismic records are mostly of good quality. Examples of records from the three types of sources are shown in Figure 2. Ice- and water-bottom arrivals (called $I_{1}$ and $I_{1} W_{1}$, respectively, after Crary and others (1962)), are clear on most of the records, although there are two sites, which could not be revisited, where the sea bed is almost certainly deeper than the bottom of the record. The deep explosive source produced the best records, whilst the hammer generally produced the worst. The shallow explosive source produced good quality ice-bottom and sca-bcd reflections but, depending on the ice thickness, the ice bottom is sometimes obscured by surface waves on a few of the channels.

$\Lambda$ s the seismic wave velocity in the water will be less 


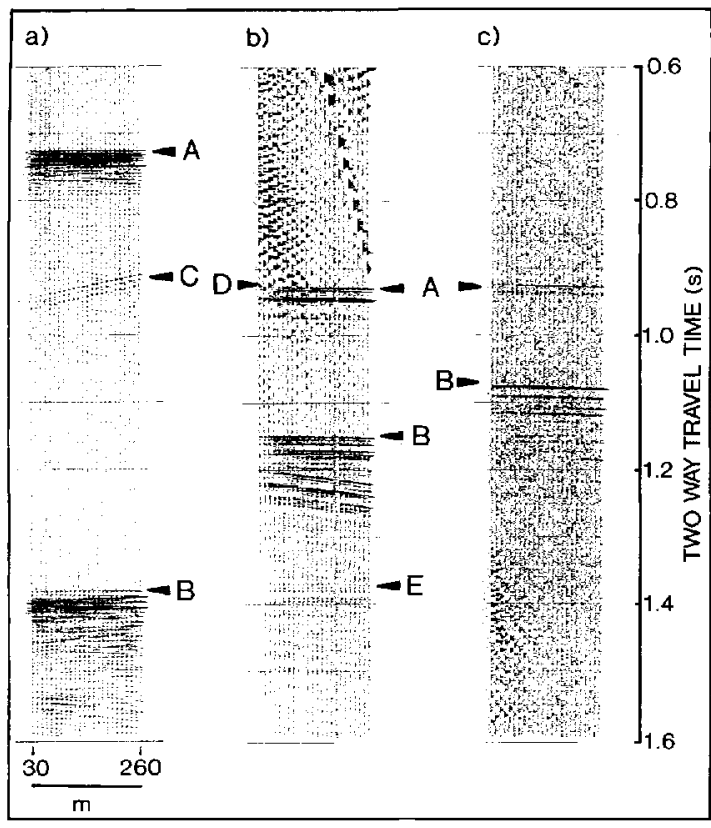

Fig. 2. Example records from each of the three source types. a. $20 \mathrm{~m}$ deep explosive charge $(100 \mathrm{~g}) .6 .1 \mathrm{~m}$ deep explosive charge $(150 \mathrm{~g})$. c. Fifleen stacked hammer blow's. The delays are different for the three records so the timescale is only absolute for $c . A$, ice bollom reflections; $B$, sea-bed reflections; $C$, arrivals from reflectors off to one side; $D$, surface waves obscuring nearer channels; $E$, weak multiple reflection from within the water layer $\left(I_{1} W_{2}\right.$ after Crary and others, 1962).

than half that in the ice, whilst the density is only slightly grcatcr, the $I_{1}$ arrival is expected to show a reversed polarity. Conversely, the increase in velocity and density across the water-bed interface means that a normal polarity reflection is expected for $I_{1} W_{1}$. These polarities are seen clearly on the records. Some confusion in interpreting the explosive-source records can come from natural acoustic energy caused by local fracturing for settling) at relatively shallow depths within the ice stream itsclf. These can usually be identified as short-period pulses travelling relatively slowly across the recording array, appcaring as stecp arrivals on the record. The hammer source is less susceptible to these arrivals, as they are unlikely to appear coherently on a number of scparate rccords which are then stacked together. Help in identifying arrivals correctly comes from the surface ghost on the deep explosive-source records. This is caused by energy which first travels upward from the shot and is then reflected downward from the free surface. Every arrival caused by the shot, rather than by natural acoustic energy, is therefore followed by an almost identical arrival around $20 \mathrm{~ms}$ later slightly less on the example given in Figure 2 a). $\triangle$ further obstacle to identifying the sea bed appears to arise from reflectors (presumably) at the bottom of the ice, off to onc side of the recording array. These appear as short sections of hyperbolic arrivals on the records and can usually be identified because they are stcep, rclatively weak and may cross onc another (c.g. just below $0.9 \mathrm{~s}$ in Figure 2a). Multiple reflections within the ice or water layers are much weaker than the primary reflections (e.g. just above $1.4 \mathrm{~s}$ in Figure 2b).

\section{CONVERSION OF TRAVEL TIMES TO DEPTHS}

After discarding the arrivals which are obriously artifacts, the ice bottom and sea bed can be confidently identified on virtually all the records. Travel times were then picked to an accuracy which depended on the sample interval and the quality of the record but were generally $\pm 0.5 \mathrm{~ms}$.

The mean velocity of compressional seismic waves in the ice column will be affected by the ice temperature and by the relatively low velocity in the shallow snow and firn. Data from a shallow refraction experiment were used to determine a correction for this low velocity (see, for example, Kirchner and Bentley, 1990) and an average velocity of $2839 \mathrm{~m} \mathrm{~s}^{-1}$ was used for the top $100 \mathrm{~m}$ of the ice columr. In the absence of direct obscrvations of velocity in the rest of the ice column, the following approach was used. By analogy with data from the Ross Ice Shelf (Robertson and Bentley, 1990), a velocity of $381 \mathrm{~m} \mathrm{~s}^{-1}$ at a depth of $100 \mathrm{~m}$ was assumed. A velocity value at the base of the icc of $3750 \mathrm{~m} \mathrm{~s}{ }^{1}$ was calculated from a velocity/temperature relationship of $2.3 \mathrm{~ms}$ ${ }^{1} \mathrm{C}^{-1}$ (Kohncn, 1974) using the observed surface temperature of $28^{\circ} \mathrm{C}$ (Jenkins and Doake, 1991). The tcmpcraturc profile within the ice is unlikely to be linear, so it was assumed that the velocity remains constant down to $300 \mathrm{~m}$ above the base, and that below this the reduction in velocity is linear. This results in an average velocity value for the ice column below $100 \mathrm{~m}$ of $3805 \mathrm{~m} \mathrm{~s}^{-1}$

The velocity $(V)$ in the sea water will depend on its temperature $(T)$, salinity $(S)$ and depth below sea level (Z). A relationship of

$$
\begin{aligned}
V= & 1449+4.6 T-0.05 T^{2}+0.0003 T^{3} \\
& +(1.39-0.012 T)(S-35)+0.017 Z
\end{aligned}
$$

(McQuillan and others, 1979) was used with values of $T=-2.2^{\circ} \mathrm{C}, S=34.6 \mathrm{ppt}$ (personal communication from A. Jenkins, 1993) and $Z=1800 \mathrm{~m}$. This gives a raluc of $1470 \mathrm{~m} \mathrm{~s}^{-1}$.

Using these velocity values, the measured reflection times were corrected for normal move-out (NMO, the increased travel time caused by increasing rcciver offset) and averaged to give the best values of ice- and watercolumn thickness at each site. The velocity in the ice is probably accurate to better than $15 \mathrm{~ms}^{1}$ which, combined with the accuracy of the travel-time picks $( \pm 0.5 \mathrm{~ms})$, gives an icc-thickness error of $\pm 7 \mathrm{~m}$. The error in water-layer thickness will be less than this as the calculated vclocity will be more accurate.

Since surface elevation was not measured directly, the sea-bed elevation was calculated assuming the ice is in hydrostatic equilibrium. This calculation included valucs of sea-water density $\left(1035 \mathrm{kgm}^{3}\right)$, from Jenkins and Doake (1991); average density of the top $100 \mathrm{~m}$ of the ice column $\left(743 \mathrm{~kg} \mathrm{~m}^{-3}\right)$ from the shallow refraction experiment; and average density of the rest of the ice column, assumed to be $917 \mathrm{~kg} \mathrm{~m}^{3}$. Assumed errors in these density values (between 5 and $10 \mathrm{~kg} \mathrm{~m}^{3}$ ) combine with the errors in thickness to give an estimated error in the bedrock elevation of $\pm 20 \mathrm{~m}$. An independent surfaceelevation measurement (from Doppler satellite positioning 
combined with a kincmatic GPS survey) is available for only one of the seismic sites (personal communication from D. G. Vaughan, 1993). This observation and the elevation derived from the hydrostatic equilibrium consideration differ by less than $1 \mathrm{~m}$. This gives some confidence in the choice of parameters and in the claimed accuracy.

\section{MAPS}

Contoured maps of ice thickness, watcr-column thickness and sea-bed elevation are given in Figure 3. The icethickness data (Fig. 3a) have been supplemented by ground-based radio-cho-sounding values from Stephenson and Doake (1982). Where points from the two data sets are near to one another, the values are reasonably close (maximum difference $56 \mathrm{~m}$ ). However, the radioecho data were obtained 13 ycars before the seismic data and ice-thickness variations with time are, in fact, likely on Rutford Ice Stream as the pattern of surface topography is seen to move downstrcam with the ice flow (Vaughan and others, 1988). Airborne radio-echosounding data are also available over this area (Doake and others, 1987) which agree with the seismic data when compared roughly, but errors in the navigation of the flight lines precludes a detailed comparison. An area of thin ice extends downstream from the grounding-line knoll. This is flanked by thicker ice, which thins again towards the ice-stream edges. This variability continucs farther downstream, with local thinner and thicker areas, in agreement with the complicated ice-thickness pattern shown by Doake and others (1987).

The water-column map (Fig. 3b) shows a smoother pattern. Compared with the ice-thickness map, this is bascd on largely the same data points so the smoothness is probably a real observation rather than an artefact of the contouring. A thin water column extends from the grounding-line knoll downstream towards the southeast. A thicker layer bounds the northeast and southwest sides of this. Thinning towards Fletcher Promontory and towards the Fllsworth Mountains must be rapid as grounded ice is close to these two thicker water columns. The start of this thinning is just observed at the site closest to the mountains.

The sea-bed clevation map (Fig. $3 c$ ) is a combination of the ice- and water-column thickness data, with the added assumption of hydrostatic equilibrium. It shows a smooth ridge running southeast from the grounding-line knoll, roughly parallel to the trend of the ice stream. Deep troughs with similar trends bound the ridge to the northeast and southwest, and must rise rapidly towards the adjacent grounded ice. Cross-sections of the ice strcam, both in the area of the seismic spot depths (Fig. 4) and from radio-echo sounding farther upstream (Doake and others, 1987), show a W-shaped profile.

No attempt has been made to calculate sea-bed dips from the observed travel times at each site, as measurements were made in only one direction. However, dip components along these directions are indicated at some sites by significant travel-time variations remaining betwcen channels after the NMO correction. These agree qualitatively with the regional trends shown by the contouring.

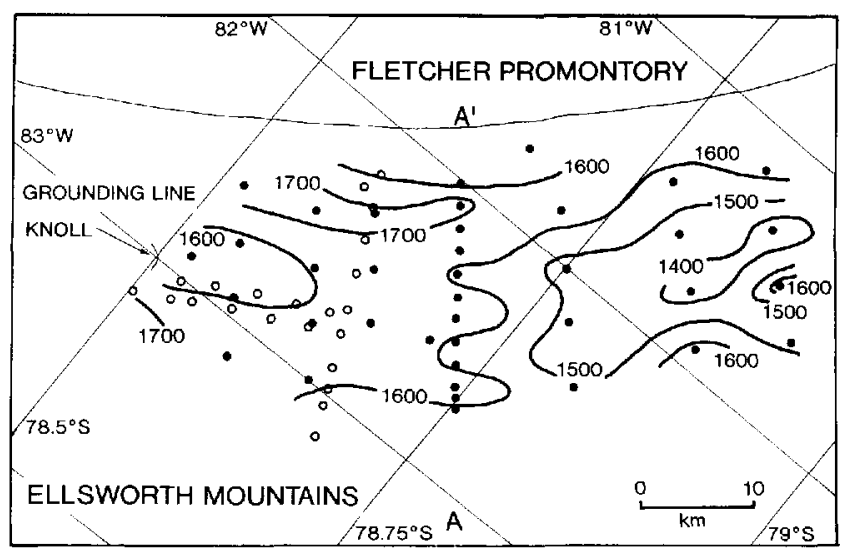

$\mathbf{a}$

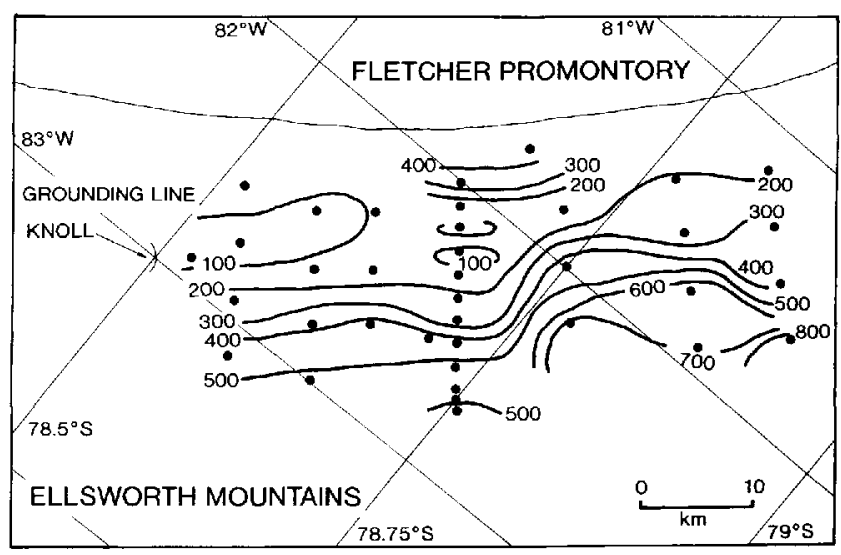

b

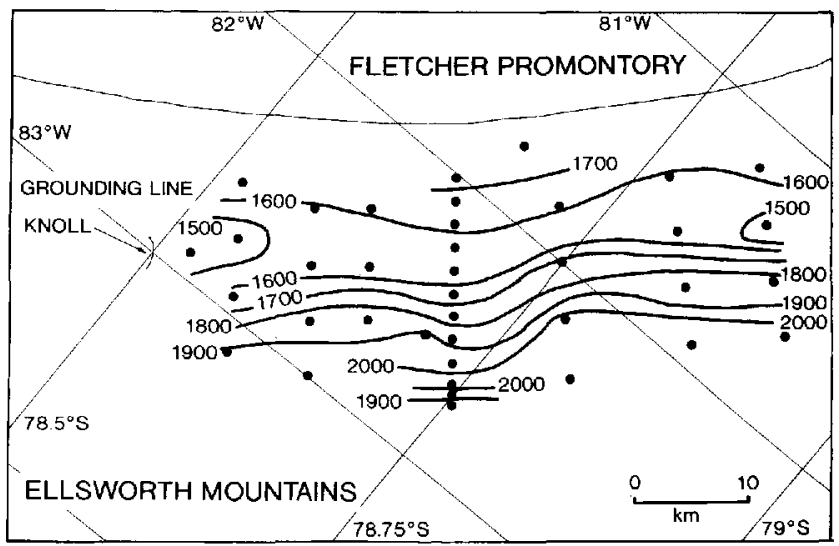

c

Fig. 3. Contour maps of (a) ice thickness $(m),(b)$ waler-column thickness $(m)$ and $(c)$ sea-bed elevation (metres below sea level). Solid circles show seismic sites. Open circles show ice-thickness dala poinls from Stephenson and Doake (1982). Ice flow is from left to right.

\section{CONGLUSIONS}

Doake and others (1987) suggested that the ice in parts of this area could be lightly grounded. If this were the case, then it is possible that the acoustic impedances of the ice and the matcrial beneath it could be very close (e.g. Shabtaie and Bentley, 1987). In this case, no reflection 


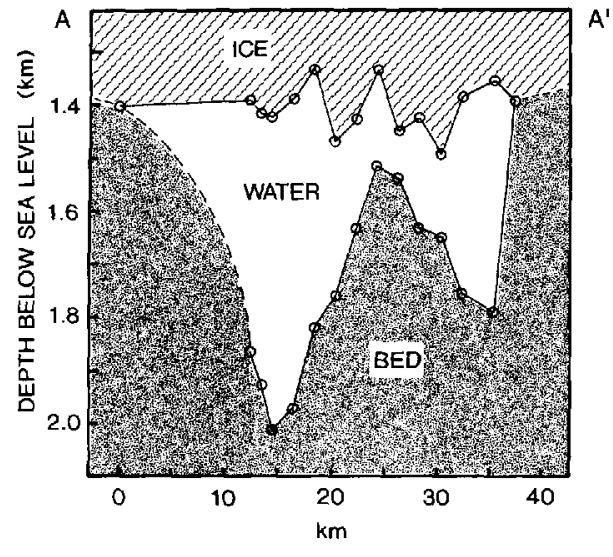

- Fig. 4. Cross-section showing ice bottom, water column and sea bed along the line $A-A^{\prime}$ in Figure $3 a$. Surface elevation and ice thickness at the two end points on the cross-section have been estimated from Sievers and others (1993) and from unpublished British Antarctic Survey data. The point showing deepest bedrock in the shallower trough has been projected from $5 \mathrm{~km}$ downstream.

would be generated at the ice-bed interface. This does not appear to be the case at any of the seismic sites. Strong arrivals with reversed polarity (as expected from an icewater interface) are consistently the first main arrival on the records. Therc are only two sites where these are not followed by an arrival which can be identified with some confidence as the sea bed, and these occur in the area of thickest water column, adjacent to the mountains.

The thin water layer (around $150 \mathrm{~m}$ thick) extending from the grounding line must restrict any transfer of water between the adjacent deeper areas, and concentrate the ebb and flow of water with the tides to these two troughs. The trough adjacent to the mountains is particularly deep (more than $2 \mathrm{~km}$ below sea level) and continues upstream, shallowing only gently for at least $170 \mathrm{~km}$ (Doake and others, 1987). As has bcen noticed before (Maslanyj and others, 1991), this deep trough represents a huge gash in the Earth's surface. A difference in bedrock elevation of around $7 \mathrm{~km}$ exists between this trough and the summit of Vinson Massif, $40 \mathrm{~km}$ away.

\section{ACKNOWLEDGEMENTS}

We thank S. Abrahams, H. Corr, S. Redshaw, Alex Taylor and Asty Taylor for their help in the ficld.

\section{REFERENCES}

Crary, A.P., E.S. Robinson, H.F. Bennett and W. W. Boyd. 1962 Glaciological studies of the Ross Ire Shelf, Antarctica, 1957-1960. IGT Glaciol. Rep. 6.

Doake, C. S. M., R. M. Frolich, D. R. Mantripp, A. M. Smith and D. G. Vaughan. 1987. Glaciological studies on Rutford Ice Stream, Antarctica. 7. Geophys. Res., 92(B9), 8951-8960.

Jenkins, A. and C.S. M. Doakc. 1991. Ice- ocean interaction on Ronne Ice Shelf, Antarctica. 7. Grophys. Res., 96(C1), 791-813.

Kirchner, J. F. and C. R. Bentley. 1990. Seismic short-refraction studies using an analytical curve-fitting technique. Antart. Res. Ser., 42, 109-126.

Kohner, H. 1974. The temperature dependence of scismic waves in ice. 7. Glaciol., 13(67), 144-147.

McQuillan, R., M. Bacon and W. Barclay. 1979. An introduction to seismic interpretation. London, Graham and Trotman.

Maslanyj, M.P., S.W. Garrett, A.C. Johnson, R. G. B. Renner and A. M. Smith. 1991. Aeromagnetic anomaly mat of West Antaricica (Weddell Sea sector). BAS GEOMAP Series, Sheet 2. I:2500100, with supplemenlary text. Cambridge, British Antarctic Survey.

Pozdeyev, V.S. and R. G. Kurinin. 1987. New data on the morphology of the icc cover and relief of the subglacial bed and sea bottom in the southern part of the Weddell Sca basin (West Antarctica). Anlarkt. Dokl. Komissii, 26, 66-71. [In Russian.]

Robertson, J.D. and C. R. Bentley. 1990. Seismic studies on the grid western half of the Ross Icc Shelf: RIGGS I and RIGGS II. Antart. Res. Ser., 42, 55-86.

Shabtaie, S. and C.R. Bentley. 1987. West Antarctic ice streams draining into the Ross Ice Shelf: configuration and mass balance. $\bar{f}$. Geophys. Res., 92(B2), 1311-1336.

Sicvers, J. and 11 others. 1993. Topographic map (satelite image map) of Filchner-Ronne-Schelfeis. 1:2000000. Frankfurt-am-Main, Institut für Angcwandte Geodüsie.

Smith, A. M. In press. Introduction to high resolution seismic survevs on the Rutford Ice Stream. In Oerter, H., ed. Filchner-Ronne-Ice-ShelfProgramme Report No. 7. Bremerhaven, Alfred Wegener Institutc.

Stephenson, S.N. and C.S.M. Doake. 1982. Dynamic behaviour of Rutford Ice Stream. Ann. Glaciol., 3, 29.j-299.

Vaughan, D.G., C.S.M. Doake and D.R. Mantripp. 1988. Topography of an Antarctic ice strcam. In Cientre Kational d' Etudes Spaizales. SPOT 1 utilisation, assessment, results. Toulousc, Cepadues-Editions, $167 \cdot 174$.

The accuracy of references in the lext and in this list is the responsibility of the authors, to whom queries should be addressed. 